\title{
Performance of Summer Mungbean (Vigna radiata L.) under Different Sowing Time at Farmers' Field
}

\author{
Navjot S. Brar, Anil Kumar and Balwinder Kumar* \\ Farm Science Centre, Guru Angad Dev Veterinary and Animal Sciences University, \\ Tarn Taran, Punjab, India \\ *Corresponding author
}

\section{A B S T R A C T}

Keywords

Monetary efficiency, Net returns, Production efficiency, Sowing time, Summer mungbean, Yield.

Article Info

Accepted:

21 June 2017

Available Online:

10 August 2017
A comparative study to evaluate the effect of different time of sowing on productivity and economics of summer mungbean (Vigna radiata L.) production was undertaken under 'Cluster Frontline Demonstrations on Pulses' of Indian Council of Agricultural Research (ICAR), New Delhi. The demonstrations were carried out in 72 different locations at farmers' fields in district Tarn Taran of Punjab. Summer mungbean variety SML 668 was supplied to all the farmers. Likewise, similar seed rate, nutrient applications and other agronomic practices were followed in all the locations of experimentation. The demonstrations were categorized into seven groups based on sowing dates and standard meteorological weeks from March 11 ( $11^{\text {th }}$ week) to April $28,2016\left(17^{\text {th }}\right.$ week). The results of investigation indicated, overall best performance of summer mungbean when sown between $18^{\text {th }}$ to $24^{\text {th }}$ March $\left(12^{\text {th }}\right.$ standard meteorological week) at all the locations of demonstration. The significant increases of 47.3 and $112.6 \%$ in economic yield was registered in crop sown between 18-24 march respectively over crop sown between the period of $15^{\text {th }}$ to $21^{\text {st }}$ April and sowing between the period of $22^{\text {nd }}$ to $28^{\text {th }}$ April. Similarly, extent of increase in biological yield with crop sown in $12^{\text {th }}$ standard meteorological week $\left(\mathrm{D}_{2}\right)$ was significantly higher by 48.4 and $84.3 \%$, respectively over crop sown in $16^{\text {th }}$ and $17^{\text {th }}$ standard meteorological week. Sowing of summer mungbean between $18^{\text {th }}$ and $24^{\text {th }}$ March also provided maximum production and monetary efficiency to the farmers. Present results thus, indicated that summer mungbean grower may get higher production and maximum economic returns by sowing crop between $11^{\text {th }}$ March and $14^{\text {th }}$ April.

\section{Introduction}

The predominance of rice-wheat cropping system in Punjab has resulted in number of ecological problems in the state such as depletion of underground water table, deterioration of soil health by adversely affecting the physical, chemical and biological properties of the soil (Kumar et al., 2016). However, for over a decade, rice- wheat cropping system yields in high productivity zones have either stagnated or declined, which is attributable to decline in total factor productivity as a result of continuous depletion in soil fertility (Shukla et al., 2005; Kumar et al., 2016; Kumar et al., 2017). In order to tackle these problems, there is need of diversification and increasing area 
under pulse crops. Pulses help in restoring fertility status of the soils by fixing atmospheric nitrogen $(\mathrm{N})$ and improve organic matter status of the soils. Pulses need less nitrogen as external input because much of their $\mathrm{N}$ requirement is met through biological N-fixation (Kumar et al., 2014; Basu et al., 2016). Moreover, pluses also act as a cheapest source of protein fulfilling and 20 to $30 \%$ of protein requirement of our population is being supplemented through pulses (Grover and Singh, 2015). The area under pulses in Punjab is declining regularly. During 1960-61, pulses were grown over 9.03 lakh hectare area with production of 7.09 lakh tons, which has declined to 61 thousand hectares with production of 44 thousand tonnes only in 2000-01. However, according to an estimate of year 2012-13, area under pulses was 64 thousand hectares with production of 53 thousand tons, indicating a slight increase in area and production under pulses (Anonymous, 2013). Inclusion of pulses in crop rotation not only plays an important role in crop diversification but, also solves the soil fertility related issues (Kumar et al., 2014). Thus, area under such crops needs to be enhanced significantly. Among pulses, mungbean being short duration crop, can fit well in the number of cropping systems and can improve soil nutrient status by fixing atmospheric N. In order to realize the potential yield of summer mungbean, sowing date plays an important role (Panwar and Sharma, 2004; Singh et al., 2010). Under Punjab conditions, very early sowing results in poor germination due to low temperature in February, while delaying in sowing resulted in coinciding of maturity stage with early rain showers resulting in serious damage to the crop. So there is dire need to guide summer mungbean growers for ideal time of sowing of this particular crop, in order to get good productivity and returns from this crop. Thus, present investigation considered above lacunas and planned at farmers' field with different time of sowing to evaluate the effect of sowing dates on crop productivity potential as well as economic returns of the farmers, so that necessary recommendations may be provided to the farmers of the area.

\section{Materials and Methods}

\section{Experimental details}

The field investigation was carried under 'Cluster Front Line Demonstrations on Pulses Programme, ICAR, New Delhi. The demonstrations were carried out in 72 different locations at farmers' fields of district Tarn Taran of Punjab. The climate of the district classified as tropical steppe, semi-arid and hot, which is mainly characterized by general dryness except for a short period during southwest monsoon season. During the summer months i.e. from April to June, weather is very hot and dry. The weather becomes hot and humid during July to September. The south-west monsoon which contributes $74 \%$, sets in last week of June and withdraws in middle of September. Maximum rain fall is received during the months July August and about 26\% occurs in the nonmonsoon months. The rainfall received during the month of April, May and June 2016 was 1.0, 28.1 and $44.9 \mathrm{~mm}$, respectively. Similarly, average maximum and minimum temperature for respective April, May and June months were ' 35 and $17^{\circ} \mathrm{C}$ ', ' 40 and $23^{\circ}$ $\mathrm{C}$ and ' 39 and $26^{\circ} \mathrm{C}$. The soils are mostly loamy to loamy sand with average $\mathrm{pH}$ value of 8.0 .

\section{Agronomic practices}

Common seed variety i.e. SML 668 of summer mungbean was supplied to all the farmers on an area of 0.4 ha. Just before sowing, the seed was treated with Rhizobium biofertilizer culture and then left to dry under shade for about 30 min followed by sowing in 
field. Urea and single super phosphate were used as source of plant nutrients and applied uniformly @ 27.5 and $100 \mathrm{Kg} \mathrm{ha}{ }^{-1}$, respectively, in all demonstrations at the time of sowing. Stomp (Pendimethalin) @ $2.5 \mathrm{ha}^{-1}$ was used to control weeds and applied with in $48 \mathrm{hrs}$ of sowing of the crop. The 72 demonstrations were divided into seven groups based on time of sowing with respect to standard meteorological weeks.

\section{Demonstrations' detail}

The details of demonstrations sown at different time period are given below:
Demonstrations (Standard Meteorological Week)

$\mathrm{D}_{1}(11)$

$\mathrm{D}_{2}(12)$

$\mathrm{D}_{3}(13)$

$\mathrm{D}_{4}(14)$

$\mathrm{D}_{5}(15)$

$\mathrm{D}_{6}(16)$

$\mathrm{D}_{7}(17)$

\section{Time of Sowing}

Sowing between the period of $11^{\text {th }}$ March to $17^{\text {th }}$ March

Sowing between the period of $18^{\text {th }}$ March to $24^{\text {th }}$ March

Sowing between the period of $25^{\text {th }}$ March to $31^{\text {st }}$ March

Sowing between the period of $1^{\text {st }}$ April to $7^{\text {th }}$ April

Sowing between the period of $8^{\text {th }}$ April to $14^{\text {th }}$ April

Sowing between the period of $15^{\text {th }}$ April to $21^{\text {st }}$ April

Sowing between the period of $22^{\text {nd }}$ April to $28^{\text {th }}$ April
The observations on different parameters viz. economic yield, biological yield, net return, benefit cost $(\mathrm{B}: \mathrm{C})$ ratio, production and monetary efficiencies were recorded. For the purpose of biological yield, the total dry matter of the crop per hectare was calculated.

\section{Production cost}

The economic analysis of the experiment was carried out by taking into consideration the them prevailing prices of inputs used and selling price of summer mungbean. The various over head costs such as that on seed bed preparation, input costs, seed treatment, plant protection, etc. had also been taken into account. Yield was also taken into account for above purpose. The production cost (Rs. ha $\left.{ }^{-1}\right)$ for raising summer mungbean, assuming owned land has been presented in table 1 .

\section{Economic returns and $\mathrm{B}: \mathrm{C}$ ratio}

The gross, net returns and $\mathrm{B}: \mathrm{C}$ ratio were calculated as follow:

Gross returns $\left(\right.$ Rs. ha $\left.{ }^{-1}\right) \quad=\quad$ Yield $\left(\mathrm{kg} \mathrm{ha}^{-1}\right) \quad \mathrm{x} \quad$ price of produce $\left(\mathrm{Rs} . \mathrm{kg}^{-1}\right)$ 
Net returns $\left(\right.$ Rs. ha $\left.{ }^{-1}\right) \quad=\quad$ Gross returns $\left(\right.$ Rs. ha $\left.{ }^{-1}\right)-\operatorname{cost}$ of cultivation $\left(\right.$ Rs. ha $\left.{ }^{-1}\right)$

Benefit cost ratio $\quad=\quad \frac{\text { Gross returns }\left(\text { Rs. ha }{ }^{-1}\right)}{\text { Cost of cultivation }\left(\text { Rs. ha }^{-1}\right)}$

\section{Harvest index}

The harvest index of the crop was calculated using following equation:

$$
\begin{aligned}
& \text { Harvest } \\
& (\%)
\end{aligned} \quad \text { Index }=\frac{\text { Seed yield }\left(\mathrm{kg} \mathrm{ha}^{-1}\right)}{\text { Biological yield }\left(\mathrm{kg} \mathrm{ha}^{-1}\right)}
$$

\section{Production and monetary efficiencies}

Production efficiency (PE) of summer mungbean $\left(\mathrm{kg} \mathrm{ha}{ }^{-1}\right.$ day $\left.^{-1}\right)$ was computed using following expression:

$$
\mathrm{PE} \quad=\frac{\begin{array}{l}
\text { Total economic yield of summer } \\
\text { mungbean }\left(\mathrm{kg} \mathrm{ha}^{-1}\right)
\end{array}}{\begin{array}{l}
\text { No. of days taken by crop from sowing } \\
\text { to harvesting }
\end{array}}
$$

Monetary efficiency (ME) (Rs. ha ${ }^{-1}$ day $^{-1}$ ) was calculated using following formula:

$\mathrm{ME}=\frac{\begin{array}{l}\text { Total net returns of summer } \\ \text { mungbean }\left(\mathrm{Rs} \mathrm{ha}^{-1}\right)\end{array}}{\begin{array}{l}\text { No. of days taken by crop from } \\ \text { sowing to harvesting }\end{array}}$

The data collected on above parameters was subjected to analysis of variance (ANOVA) using the SPSS statistical package. The comparison of treatment means was made by Tukey $(\mathrm{CD})$ at $p=0.05$.

\section{Results and Discussion}

\section{Biological yield}

Time of sowing affected the biological yield significantly (Table 2). Maximum biological yield was recorded with sowing dates between the period of $18^{\text {th }}-24^{\text {th }}$ March $\left(D_{2}\right)$, however, it was found statistically at par with the demonstration sown on dates $D_{1}\left(11^{\text {th }}\right.$ $17^{\text {th }}$ March $), D_{3}\left(25^{\text {th }}-31^{\text {st }}\right.$ March $), D_{4}\left(1^{\text {st }}-\right.$ $7^{\text {th }}$ April), $\mathrm{D}_{5}\left(8^{\text {th }}-14^{\text {th }}\right.$ April) (Table 2). The demonstrations sown between $12^{\text {th }} \mathrm{SW}\left(\mathrm{D}_{2}\right)$ was found significantly superior over $D_{6}$ i.e. crop sown between the period of $15^{\text {th }}-21^{\text {st }}$ April and $\mathrm{D}_{7}\left(22^{\text {nd }}-28^{\text {th }}\right.$ April $)$. The magnitude of increase in biological yield with $\mathrm{D}_{2}$ was to the tune of 48.4 and $84.3 \%$, respectively over $\mathrm{D}_{6}$ and $\mathrm{D}_{7}$. The above trend indicated the best suitability of sowing summer mungbean between $18^{\text {th }}$ to $24^{\text {th }}$ March. The later sowing time also performs statistically similar but, yield decreased numerically. A drastic decrease in biological yield was observed after $14^{\text {th }}$ April (Table 2). The findings of Kumar et al., (2009) and Ram et al., (2016) also support current results presented above.

\section{Economic yield}

Likewise biological yield, different time of sowing influenced economic yield of summer mungbean significantly (Table 2). Maximum economic yield was registered following sowing of crop between $18^{\text {th }}$ and $24^{\text {th }}$ March $\left(D_{2}\right)$, however, it was found statistically at par with $D_{1}\left(11^{\text {th }}-17^{\text {th }}\right.$ March $), D_{3}\left(25^{\text {th }}-31^{\text {st }}\right.$ March $), D_{4}\left(1^{\text {st }}-7^{\text {th }}\right.$ April $), D_{5}\left(8^{\text {th }}-14^{\text {th }}\right.$ April) (Table 2). The demonstrations sown between $12^{\text {th }}$ SW $\left(\mathrm{D}_{2}\right)$ were found significantly superior over $\mathrm{D}_{6}$ and $\mathrm{D}_{7}$. The extent of increase in economic yield following demonstration $\mathrm{D}_{2}$ was 47.3 and $112.6 \%$, respectively over $\mathrm{D}_{6}$ and $\mathrm{D}_{7}$ (Table 2). 
Realising higher seed yield of summer mungbean from the crop sown between $18^{\text {th }}$ and $24^{\text {th }}$ March, indicating its best suitability for sowing in the area. The later sowing time also performed statistically similar but, yields decrease numerically. A significant decrease in crop yield was observed after $14^{\text {th }}$ April (Table 2). Moreover, due to higher rainfall intensity in the month of June $(44.9 \mathrm{~mm})$, there was an incident of whitefly, which resulted in transmission of yellow mosaic virus disease and caused significant economic loss to productivity particularly in late sown crop. The findings of current study are in conformity with the observations of Singh and Singh (2009), who registered significantly higher grain yield of summer mungbean, when it was sown in between March $20^{\text {th }}$ - April $1^{\text {st }}$ than sown during $10^{\text {th }}$ $20^{\text {th }}$ April. The findings of Kumar et al., (2009) and Ram et al., (2016) also support current results presented above.

\section{Harvest index}

The highest value of harvest index was registered with demonstrations $D_{1}$ and $D_{3}$, which were however found statistically similar with $\mathrm{D}_{2}$ (Table 2). Moreover, above treatments were also recorded statistically at par with demonstrations $\mathrm{D}_{4}, \mathrm{D}_{5}$ and $\mathrm{D}_{6}$. The demonstration $\mathrm{D}_{7}$ performed significantly inferior to all other treatments evaluated in the experimentation (Table 2). Singh and Singh (2009) also reported decrease in summer mungbean yield and yield under late sown conditions resulting in low value of harvest index.

\section{Net returns}

Maximum net returns were recorded with $D_{2}$ i.e. demonstrations sown between the period of $18^{\text {th }}-24^{\text {th }}$ March followed by $D_{1}\left(11^{\text {th }}\right.$ $17^{\text {th }}$ March), both of which were recorded statistically similar with each other. Moreover, demonstrations $\mathrm{D}_{1}$ and $\mathrm{D}_{2}$ were also observed statistically at par with $\mathrm{D}_{4}$ and $D_{5}$, but significantly superior to $D_{6}$ and $D_{7}$ treatments (Table 2). The magnitude of increase in net returns in the demonstration $\mathrm{D}_{2}$ was $37.1 \%$ more over $\mathrm{D}_{6}$. Similarly, treatment $\mathrm{D}_{1}$ gave significantly higher net returns as compared to $\mathrm{D}_{6}$ by $94.2 \%$, respectively (Table 2).

\section{Profitability (B:C ratio)}

As regard $\mathrm{B}: \mathrm{C}$ ratio (profitability), respective significant increase of 45.1 and $111.4 \%$ were recorded with demonstration $\mathrm{D}_{2}$ in comparison with $\mathrm{D}_{6}$ and $\mathrm{D}_{7}$ (Table 2). Likewise, extent of increase in $\mathrm{B}: \mathrm{C}$ ratio was 29.4 and $88.6 \%$ under demonstration $\mathrm{D}_{1}$ over $\mathrm{D}_{6}$ and $\mathrm{D}_{7}$, respectively. The demonstrations $\mathrm{D}_{6}$ and $\mathrm{D}_{7}$ were recorded significantly inferior to all other treatments, both in case of net returns and benefit cost ratio (Table 2). The higher productivity of summer mungbean with $D_{2}$ is the reason of higher returns and $\mathrm{B}: \mathrm{C}$ ratio to the farmers and as discussed above, this was the best suited time of sowing for summer mungbean cultivation. Later sowing dates caused economic loss to summer mungbean growers due to decreased seed yield (Table 2 ).

\section{Production efficiency}

The highest production efficiency was registered in demonstration $\mathrm{D}_{2}$ i.e. sowing of crop between $18^{\text {th }}$ and $24^{\text {th }}$ March followed by $\mathrm{D}_{1}\left(11^{\text {th }}-17^{\text {th }}\right)$ and $\mathrm{D}_{5}\left(8^{\text {th }}-14^{\text {th }}\right.$ April) (Fig. 1). The magnitude of increase in production efficiency with $\mathrm{D}_{2}$ was to the extent of $10.5 \%$ and $21.0 \%$ over $\mathrm{D}_{1}$ and $\mathrm{D}_{5}$, respectively (Fig. 1). However, demonstrations $D_{1}$ and $D_{5}$ were recorded statistically at par with each other. A sharp decrease in above parameter was registered in remaining demonstrations as the sowing time was delayed. Overall, treatment $\mathrm{D}_{7}$ was found significantly inferior to all the demonstrations (Fig. 1). The highest 
production efficiency in $\mathrm{D}_{2}$ is attributed to better crop yields governed by timely sowing of summer mungbean coupled with favourable soil and climatic conditions (Singh and Singh 2009).

\section{Monetary efficiency}

Monetary efficiency was recorded significantly higher with demonstration $\mathrm{D}_{2}$ followed by $\mathrm{D}_{1}$ and $\mathrm{D}_{5}$. However, demonstrations $\mathrm{D}_{2}$ and $\mathrm{D}_{1}$ were reported statistically at par with each other (Fig. 2). The respective increases in monetary efficiency following demonstration $\mathrm{D}_{2}$ was to the tune of 21.6 and $48.7 \%$ in comparison with $\mathrm{D}_{1}$ and $\mathrm{D}_{5}$. The demonstrations $\mathrm{D}_{3}, \mathrm{D}_{4}$ and $\mathrm{D}_{5}$ gave statistically similar monetary efficiency (Fig. 2). The $\mathrm{D}_{7}$ was registered significantly inferior to all other demonstrations. Higher net returns from crop under timely sowing conditions may be the probable reason of higher monetary efficiency under $\mathrm{D}_{2}$ demonstration in current study. In other words, it may be inferred that sowing of summer mungbean between $18^{\text {th }}$ and $24^{\text {th }}$ March gave maximum production and returns per day. The benefits from the crop in term of production and monetary efficiency decreased drastically as the sowing time are delayed.

Table.1 Cost of cultivation (Rs. ha ${ }^{-1}$ ) for raising summer mungbean (assuming owned land)

\begin{tabular}{|c|c|}
\hline Input factors & Cost \\
\hline Seed Cost (@Rs 120 kg-1) & 4500 \\
\hline Herbicide cost (Stomp @ Rs $500 \mathrm{~L}^{-1}$ ) & 1250 \\
\hline Fertilizer (Urea@Rs $5.5 \mathrm{Kg}^{-1}$ and SSP @ Rs Rs $8 \mathrm{Kg}^{-1}$ ) & 2152 \\
\hline Insecticides (Chlorpyriphos @ Rs 250L $\mathrm{L}^{-1}$ and Triazophos @ Rs 440L ${ }^{-1}$ ) & 1600 \\
\hline Human Labour cost & 14800 \\
\hline Tractor hours (Rs $385 \mathrm{hr}^{-1}$ ) & 3080 \\
\hline Irrigation (Rs 100 irrigation $^{-1}$ ) & 200 \\
\hline Transportation and Marketing & 650 \\
\hline Quarterly interest on variable cost @ 9\% & 635 \\
\hline Total cost of cultivation & 28867 \\
\hline
\end{tabular}


Table.2 Yield and economics of summer mungbean with different time of sowing

\begin{tabular}{|c|c|c|c|c|c|}
\hline $\begin{array}{l}\text { Time of Sowing } \\
\text { (Standard } \\
\text { Meteorological Week) }\end{array}$ & $\begin{array}{c}\text { Biological } \\
\text { yield } \\
\left(\mathbf{q} \text { ha }^{-1}\right)\end{array}$ & $\begin{array}{c}\text { Economic } \\
\text { Yield } \\
\left(\mathbf{q} \mathbf{h a}^{-1}\right)\end{array}$ & $\begin{array}{c}\text { Harvest } \\
\text { Index }\end{array}$ & $\begin{array}{c}\text { Net } \\
\text { return } \\
\left(\mathrm{Rs} \mathrm{ha}^{-1}\right)\end{array}$ & BC Ratio \\
\hline $\mathrm{D}_{1}(11)$ & $36.27^{\mathrm{ab}}$ & $11.20^{\mathrm{ab}}$ & $0.31^{\mathrm{a}}$ & $28395^{\mathrm{ab}}$ & $1.98^{\mathrm{ab}}$ \\
\hline $\mathrm{D}_{2}(12)$ & $40.64^{\mathrm{a}}$ & $12.23^{\mathrm{a}}$ & $0.30^{\mathrm{a}}$ & $34660^{\mathrm{a}}$ & $2.22^{\mathrm{a}}$ \\
\hline $\mathrm{D}_{3}(13)$ & $31.10^{\mathrm{ab}}$ & $9.47^{\mathrm{ab}}$ & $0.31^{\mathrm{a}}$ & $20347^{\mathrm{ab}}$ & $1.70^{\mathrm{abc}}$ \\
\hline $\mathrm{D}_{4}(14)$ & $33.77^{\mathrm{ab}}$ & $9.89^{\mathrm{ab}}$ & $0.29^{\mathrm{ab}}$ & $25555^{\mathrm{ab}}$ & $1.79^{\mathrm{ab}}$ \\
\hline $\mathrm{D}_{5}(15)$ & $36.64^{\mathrm{ab}}$ & $10.01^{\mathrm{ab}}$ & $0.27^{\mathrm{ab}}$ & $23166^{\mathrm{ab}}$ & $1.81^{\mathrm{ab}}$ \\
\hline $\mathrm{D}_{6}(16)$ & $27.38^{\mathrm{bc}}$ & $8.38^{b c}$ & $0.28^{\mathrm{ab}}$ & $14618^{b c}$ & $1.53^{\mathrm{bc}}$ \\
\hline $\mathrm{D}_{7}(17)$ & $22.05^{\mathrm{c}}$ & $5.75^{\mathrm{c}}$ & $0.26^{\mathrm{b}}$ & $1033^{c}$ & $1.05^{\mathrm{c}}$ \\
\hline
\end{tabular}

Note: Means with different letters are significantly different at the 0.05 level of significance

Fig.1 Production efficiency of summer mungbean with different time of sowing (Means with different letters above bars are significantly different at the 0.05 level of significance)

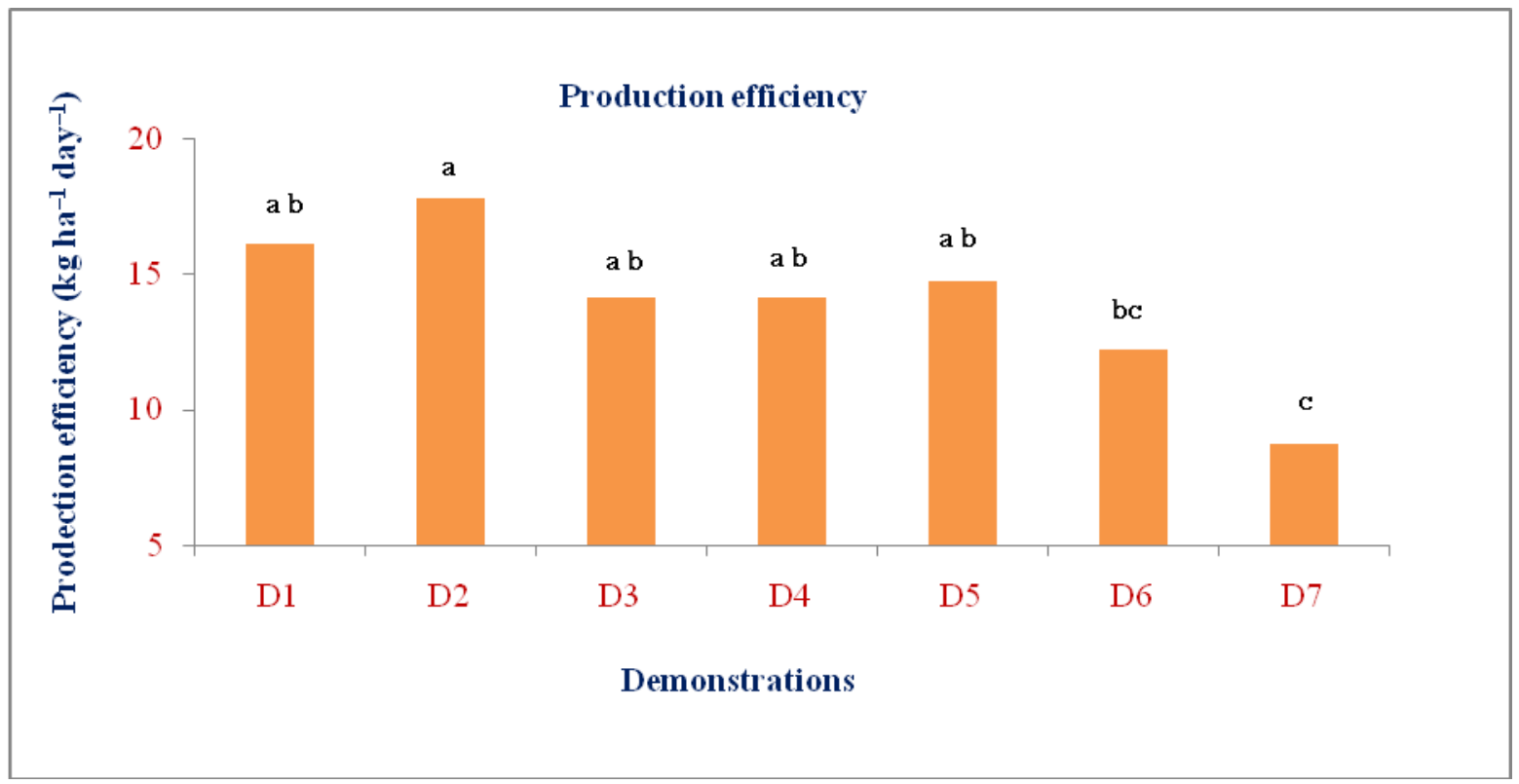


Fig.2 Monetary efficiency of summer mungbean with different time of sowing (Means with different letters above bars are significantly different at the 0.05 level of significance)

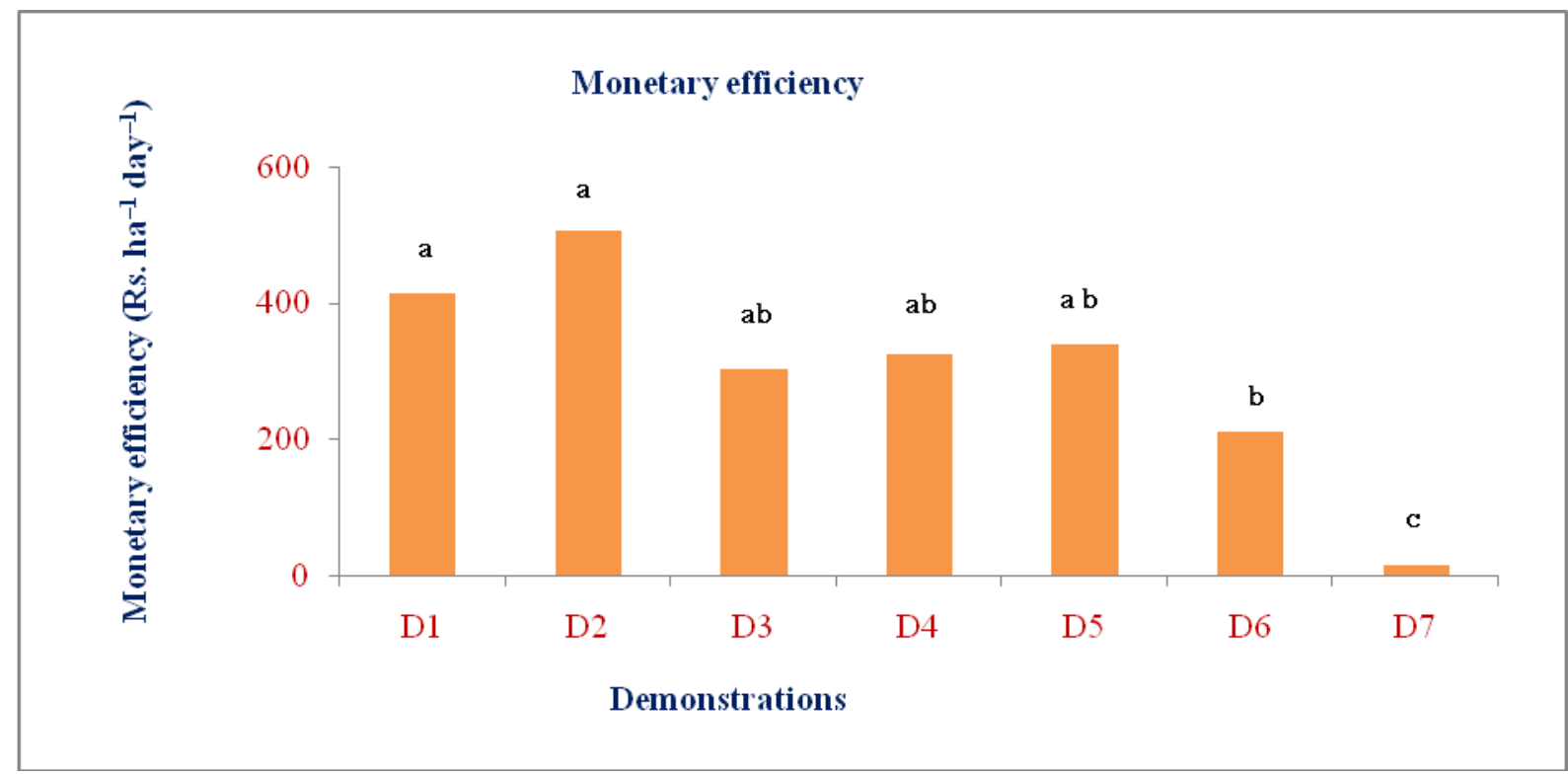

In conclusion, results on demonstrations indicated maximum production and economic benefit to summer mungbean grower when crop was sown between $11^{\text {th }}$ March and $14^{\text {th }}$ April. Summer mungbean sowing during this period also gave maximum production and monetary returns to the farmers. The benefits from the crop in term of production and monetary efficiency, however, decreased drastically as the sowing time is delayed. Overall, demonstrations sown during above time spell gave best performance in term of productivity and profitability to the farmers. Delayed sowing (after April 14) led to infestation of whitefly and transmission of yellow mosaic virus disease resulting lesser seed yield. Moreover, crop's maturity period coincide with early monsoon, which may result in significant loss of crop yield and economic returns.

\section{Acknowledgement}

The authors are thankful to Indian Council of Agricultural Research (ICAR), New Delhi,
India for providing financial assistance to carry out above study under Cluster Frontline Demonstration Programme on Oilseed and Pulses.

\section{References}

Anonymous. 2013. Statistical Abstract of Punjab. Economic and Statistical Organisation, Punjab, Chandigarh.

Basu, P.S., U. Singh, A. Kumar, C.S. Praharaj and Shivran, R.K. 2016. Climate change and its mitigation strategies in pulses production. Indian J. Agron., 61: 71-82.

Grover, D.K., and Singh, J.M. 2015. Fiscal viability of pulses cultivation in Punjab: An economic analysis. Indian J. Agri. Res., 49: 392-399.

Kumar, A., N.S. Brar, S. Pal and Singh P. 2017. Available soil macro and micronutrients under rice wheat cropping system in District Tarn Taran of Punjab. Ecol. Environ. Conservation, 23(1): 202-207.

Kumar, B., U.S. Tiwana, A. Singh, and Ram, 
H. 2014. Productivity and quality of intercropped maize (Zea mays L.) + cowpea [Vigna unguiculata (L.) Walp.] fodder as influenced by nitrogen and phosphorus levels. Range Management and Agroforestry, 35(2): 263-267.

Kumar, R., R. Nandan, V. Kumar, S. Prasad and Singh, D. 2009. Response of summer mungbean (Vigna radiata) cultivars to sowing time and seed rate. Indian J. Agri. Sci., 79: 309-312.

Kumar, S.S. Dhaliwal, S.T. Singh, J.S. Lamba, and Ram, H. 2016. Herbage production, nutritional composition and quality of teosinte under Fe fertilization. Int. J. Agri. Biol., 18(2): 319-329.

Panwar, G., and Sharma, B.B. 2004. Effect of planting date, seed rate and row spacing on yield and yield attributes of bold seeded mungbean during spring/summer season. Indian J. Pulses Res., 17: 45-46.
Ram, H., N. Aggarwal, G. Singh and Singh, S. 2016. Heat and water-use efficiency in summer mungbean (Vigna radiata $L$. Wilczek) under different thermal and moisture regimes. J. Agrometeorol., 18: 196-200

Shukla, A.K., S.K. Sharma, R. Tiwari, and Tiwari, K.N. 2005. Nutrient depletion in the rice-wheat cropping system of the Indo-Gangetic plains. Better Crops, 89(2): 28-31.

Singh, G., H.S. Sekhon, H. Ram, K.K. Gill and Sharma, P. 2010. Effect of date of sowing on nodulation, growth, thermal requirement and grain yield of kharif mungbean genotypes. J. Food Legumes, 23: $132-134$.

Singh, S. and Singh, G. 2009. Effect of sowing dates on growth and yield of mungbean genotypes during summer season. J. Food Legumes, 22: 305-307.

\section{How to cite this article:}

Navjot S. Brar, Anil Kumar and Balwinder Kumar. 2017. Performance of Summer Mungbean (Vigna radiata L.) under Different Sowing Time at Farmers' Field. Int.J.Curr.Microbiol.App.Sci. 6(8): 2211-2219. doi: https://doi.org/10.20546/ijcmas.2017.608.260 